\title{
THE FATTY ACIDS OF TOTAL LIPIDS AND CHOLESTEROL ESTERS FROM NORMAL PLASMA AND ATHEROMATOUS PLAQUES ${ }^{1}$
}

\author{
By NAIP TUNA, LOIS RECKERS, AND IVAN D. FRANTZ, JR.
}

(From the Cardiovascular Research Laboratory, Department of Medicine, University of Minnesota Medical School, Minneapolis, Minn.)

(Submitted for publication September 23, 1957; accepted April 24, 1958)

In order to elucidate the mechanism of atheroma formation in arteriosclerosis, the lipid fractions of plasma and atheromatous plaques have been extensively studied in the past 45 years. It was first noted that there is a high content of cholesterol, phospholipid and total extractable lipids in atheromatous aortas $(1-4)$. Then came a period when studies dealt primarily with the changing ratios between total, free and esterified cholesterol and phospholipids in normal plasma and atheromatous plaques (5-8). Considerable work has been done in the past decade to correlate the changes in blood cholesterol, phospholipids and lipoproteins with the incidence of arteriosclerosis (9-15). Comparatively little work has been done, however, on the isolation and identification of fatty acids associated with different lipid fractions of plasma and atheromatous plaques, the lack of adequate methods for fatty acid analysis being the most likely explanation. Schoenheimer (3) isolated the cholesterol esters of stearic, oleic and palmitic acids from the adventitia-free atheromatous aorta. In addition to these acids, McArthur (16) isolated linoleic and arachidonic acids from aortic plaques. As far as the fatty acids of the blood are concerned, the main sources of information are alkali isomerization studies (17-19) and studies done on the blood of large mammals (20). Recently, more information based on paper (21), column (22) and gas-liquid (23) chromatographic analysis of fatty acids of human blood has been reported. However, no comparative studies are available on material from human beings, using the same analytical methods to determine the fatty acids in blood and atheromatous plaques. There have been isolated reports suggesting that the blood of popu-

1 This work was supported by grants from the Minnesota Heart Association, and by a grant (No. H-1875) from the National Heart Institute, United States Public Health Service. lation groups having a low incidence of arteriosclerosis contains lipids of high iodine value (24). Another report has suggested that the feeding of fats with a high content of linoleic acid will raise the iodine value of the blood lipids, in addition to lowering the blood cholesterol (25). It has also been suggested that arteriosclerosis may develop as a result of essential fatty acid deficiency, or that the saturated acids, by virtue of their relative insolubility, may deposit preferentially in the arterial wall, thus playing an important role in the development of arteriosclerosis $(26,27)$. Since changes in blood cholesterol levels have been produced by feeding different fats, and speculations have been advanced as to the importance to be attributed to different types of.fats in the production of arteriosclerosis (28-31), we have undertaken the present investigation in an effort to determine and compare the fatty acids of sterol esters and of total lipids (including triglycerides, cholesterol esters, phospholipids and free fatty acids) in normal plasma and atheromatous plaques, with the hope that such a study might shed light on the problem of atheroma formation.

\section{MATERIALS AND METHODS}

The lipids to be analyzed were obtained from normal blood and from atheromatous plaques. The fatty acids of total lipids and of cholesterol esters were first separated by counter-current distribution. The peaks were analyzed by means of alkali isomerization, determination of iodine value, gas-liquid chromatography, and paper chromatography before and after hydrogenation. The details are as follows:

Fasting venous blood from eight normal persons, who were considered to be in good health and good nutritional state and clinically free of arteriosclerosis and gross metabolic abnormalities, was collected in bottles containing sodium citrate as anticoagulant. Plasma was separated by centrifugation, pooled, and the total lipids extracted with $2: 1$ chloroform-methanol mixture $(\mathrm{v} / \mathrm{v})$ and purified according to the method of Folch and co-workers (32). The solvents were evaporated at $45^{\circ} \mathrm{C}$. in vacuo 
in a flash evaporator (33). The total lipids were dissolved in a chloroform-methanol mixture. Aliquots were taken for the chromatographic separation of cholesterol esters, and for saponification with 15 per cent alcoholic $\mathrm{KOH}$ in order to obtain the fatty acids of total lipids. Saponification was carried out under an atmosphere of nitrogen, with refluxing, for five hours. Under these circumstances, no appreciable conjugation of poly-unsaturated fatty acids occurred.

Aortas were obtained from autopsy material. The intima was carefully separated from the media and outer layer, and the plaques were dissected. Most of the plaques were either calcified or ulcerated. They were cut into small pieces and then extracted with 2: 1 chloroform-methanol mixture $(v / v)$. For each gram of wet plaques approximately $20 \mathrm{ml}$. of solvent mixture was used. Extraction with the boiling solvent was continued for 30 minutes. The extraction was repeated four times with fresh solvent mixture. When aliquots of aortic plaques that had been extracted according to this method were hydrolyzed with ethanolic $\mathrm{KOH}$ solution, acidified and extracted with petroleum ether, no weighable amount of substance was obtained. The extracts were filtered, pooled and "purified" in a large water bath (32). The lipids were recovered from the extracts and treated further in the same way as described above for the lipids of plasma.

The chromatographic separation of sterol esters was done according to Borgström's method (34). The silicic acid $^{2}$ was used without prior activation. It was mixed with half its weight of Super-Cel, ${ }^{3}$ and the slurry made in light petroleum ether (boiling range, 30 to $60^{\circ}$ C.) was packed in columns of various sizes $(2$ to $8 \mathrm{~cm}$. in diameter). The height of the columns was 9 to $10 \mathrm{~cm}$. For a $2 \mathrm{~cm}$. column, $300 \mathrm{mg}$. of total lipids was used, larger amounts being used with larger columns. The sterol esters were eluted with $8: 2$ light petroleum ether-benzene mixture $(\mathrm{v} / \mathrm{v})$.

The sterol esters were tested for contamination with other lipids as follows: Phosphorus was determined by the method of Lowry and associates (35). Free cholesterol was determined by the modified SchoenheimerSperry method (36). Free fatty acids were titrated with $0.01 \mathrm{~N}$ methanolic $\mathrm{KOH}$. The upper limits of contamination, measured in these ways, were: free cholesterol, 0.3 per cent; phospholipid, 0.1 per cent; free fatty acids, 1 per cent. We had no satisfactory method for minute amounts of glycerol, and are unable to give meaningful figures for contamination with triglycerides. It was felt, however, that contamination with triglycerides was also quite small, since the total cholesterol content varied between 57.7 and 60.5 per cent, as determined by the method of Abell, Levy, Brodie, and Kendall (37) or by the modified Schoenheimer-Sperry (36) method. The

2 Mallinckrodt Chemical Works, 100 mesh, analytical reagent, suitable for chromatographic analysis by the method of Ramsey and Patterson.

3 Johns-Manville Corp. theoretical cholesterol content, as calculated after the amounts of the various fatty acids present had been determined, was 59.9 per cent.

The cholesterol esters were saponified with alcoholic $\mathrm{KOH}$ in the same manner as the total lipids. The soaps from both of these sources were dissolved by heating in distilled water, and the unsaponifiable substances were removed by extraction five or six times with light petroleum ether. The soap solution was acidified with 50 per cent concentrated $\mathrm{HCl}$ in water and the fatty acids extracted three times with light petroleum ether. The extract was washed with distilled water until the water was neutral to litmus paper. It was dried with anhydrous sodium sulfate, and the solvents were evaporated in vacuo.

Separation and characterization of fatty acids: Countercurrent distribution. Distributions were carried out in a 200 cell, all glass, fully automatic machine described by Craig, Hausmann, Ahrens, and Harfenist (38). The solvent system used was a mixture of $n$-heptane, glacial acetic acid, formamide and methanol in the proportions $3: 1: 1: 1$ (39). About 1.5 to $2.5 \mathrm{Gm}$. of fatty acids was dissolved in lower phase previously equilibrated with upper phase, and distributed for about 420 transfers. The volumes of the upper and lower phases were each approximately $10 \mathrm{ml}$. After completion of the distributions, the concentrations of the fatty acids were determined by sampling the upper phase in every fourth tube. For complete recovery of the various acids, all of the solute in each tube was displaced into the upper phase by addition of water. The lower phase was then extracted three times with fresh $n$-heptane. The recoveries totalled 95 to 99 per cent of the weight of the acids distributed.

Fractions were recovered from the peaks and from different parts of the limbs of all curves for characterization and quantitation of the constituents present.

Iodine value. Iodine values were determined on 2 to $10 \mathrm{mg}$. samples, which were dissolved in $0.5 \mathrm{ml}$. of carbon tetrachloride and incubated for 45 minutes with $1 \mathrm{ml}$. of Wijs solution (40). After addition of $0.5 \mathrm{ml}$. of 15 per cent potassium iodide and $3 \mathrm{ml}$. of distilled water, the samples were titrated with $0.2 \mathrm{~N}$ thiosulfate solution, using an amperometric method suggested by Kolthoff and Bovey (41). All determinations were carried out in duplicate. The difference in the results of the duplicates was less than 1 per cent. The iodine values obtained on pure oleic and linoleic acids by this method agreed with values calculated from quantitative hydrogen uptake determinations done according to Pack, Planck, and Dollear (42).

Alkali isomerization. Alkali isomerization was done according to Herb and Riemenschneider (18). The recording of spectra between 230 and $380 \mathrm{~m} \mu$ was done with a Model DK Beckman spectrophotometer.4

Paper chromatography. Paper chromatography of fatty acids was done on Whatman No. 3 paper impregnated with 10 per cent (v/v) liquid petrolatum, U.S.P.,

${ }^{4} \mathrm{We}$ are grateful to Mr. Page R. Edmondson for recording these spectra. 
TABLE I

Retention volumes of methyl esters of various fatty acids

\begin{tabular}{lc}
\hline \hline Compound & $\begin{array}{c}\text { Retention } \\
\text { vol. } \\
\left(\mathbf{V}^{\prime} \mathbf{R}\right) *\end{array}$ \\
\hline Methyl laurate & $(\mathrm{ml})$. \\
Methyl myristate & 34 \\
Methyl palmitate & 60 \\
Methyl stearate & 94 \\
Methyl arachidate & 167 \\
Methyl behenate & 286 \\
\end{tabular}

* Corrected for the pressure drop across the column. Conditions of chromatography as in Figure 1.

in ethyl ether. For short chain or highly unsaturated fatty acids, low concentrations ( 70 to 75 per cent) of acetic acid were used, and for longer chain or saturated fatty acids, higher concentrations ( 85 to 95 per cent). Staining of chromatograms was done according to Mangold, Lamp, and Schlenk (43). The unsaturated fatty acids were stained with iodine vapors. The chromatograms of saturated fatty acids were stained with iodine vapors after they had first been sprayed with 1 per cent $\alpha$-cyclodextrin in 30 per cent ethanol.

Gas-liquid chromatography. 5 These analyses were carried out in a Podbielniak "Chromacon," Model 9475. The column was $4 \mathrm{~mm}$. in diameter and 18 inches long, and consisted of 5 per cent silicone grease ${ }^{6}$ on sodium chloride. The column temperature was kept constant at 234 to $235^{\circ} \mathrm{C}$., and the sample heater temperature at $270^{\circ} \mathrm{C}$. Helium gas, at a flow rate of 11.6 to $12.8 \mathrm{ml}$. per minute, was used for elution. The fatty acids were first esterified using diazomethane, prepared according to a standard method (44). The solution of diazomethane was added to an ethereal solution of fatty acids until a yellow color persisted. When the esterification was complete, the ether was evaporated and the methyl esters were dissolved in petroleum ether. Two and five-tenths to $4 \mu \mathrm{l}$. of solution containing 0.5 to $1 \mathrm{mg}$. of solute was placed on the column. The corrected retention volumes $\left(V^{\prime} R\right)$ were compared with those of known acids. Figure 1 shows the gas-liquid chromatographic analysis of a mixture of known saturated fatty acids from $C_{12}$ to $C_{22}$. Table I shows the corrected retention volumes ( $\left.V^{\prime} R\right)$ of these acids. Under the conditions specified, the separatory power of this column, when calculated for stearic acid, was found to be 185 theoretical plates. With this column it was not possible to separate saturated and unsaturated fatty acids having the same chain length, although the retention volumes were not quite identical. In order to obtain analyses according to chain length

$5 \mathrm{We}$ are indebted to $\mathrm{Dr}$. D. H. Wheeler and $\mathrm{Mr}$. J. Nelson of the General Mills Research Laboratories, Minneapolis, for the gas-liquid chromatographic analyses.

6 Dow Corning high vacuum silicone grease was treated according to Cropper and Heywood (45).

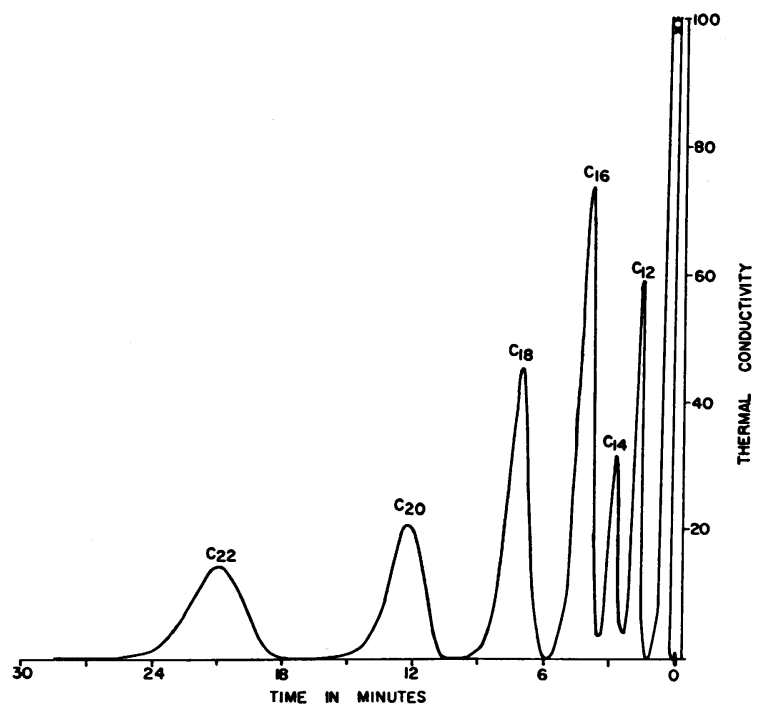

Fig. 1. Gas-Liquid Chromatogram of a Known Mixture of the Methyl Esters of Lauric, Myristic, Palmitic, Stearic, Arachidic and Behenic Acids

Sample size, $5 \mu 1$. ( $1 \mathrm{mg}$. fatty acids); column length, 18 inches, diameter (i.d.), $4 \mathrm{~mm}$.; liquid phase, 5 per cent silicone grease on $\mathrm{NaCl}$; column temp., $235^{\circ} \mathrm{C}$.; flow rate of helium (at the inlet), $12.8 \mathrm{ml}$. per minute; inlet pressure, $110 \mathrm{~mm}$. $\mathrm{Hg}$; outlet pressure, atmospheric.

$\mathrm{O}$, sample injection point; $\mathrm{X}$, solvent peak.

The numbers on the ordinate are arbitrary units.

only, with complete elimination of the effect of unsaturation, some of the samples were hydrogenated and then analyzed by gas-liquid chromatography. The areas under the peaks were used to calculate the per cent composition of the samples examined, and the results were compared with those obtained from iodine value and alkali isomerization.

\section{RESULTS}

\section{Fatty acids from total lipids of atheromatous plaques}

One and seven-tenths $\mathrm{Gm}$. of fatty acids obtained from the total lipids of pooled atheromatous plaques was subjected to counter-current distribution (Figure 2). The curve was divided into six fractions (Fractions $A$ through $F$ of Figure 2 and Table II). The contents of the tubes in each fraction were pooled, and the fatty acids were identified further by the methods discussed above.

Fraction $D$ (tubes 100 through 143, less the peak tubes 123 through $127^{7}$ ). This fraction will

7 These numbers, as well as the tube numbers included in the figures and tables, represent the tube numbers in the apparatus. For the calculation of partition ratios, 200 must be added to all of them, since all of the solutes had made somewhat more than one full circuit. 


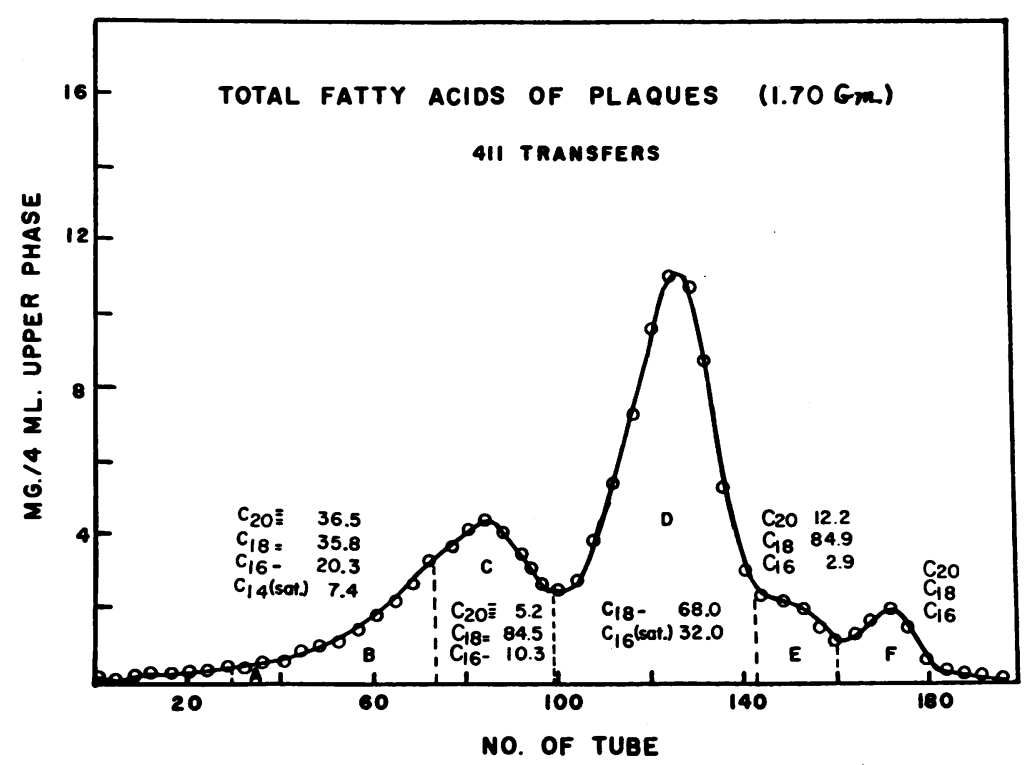

Fig. 2. Counter-Current Distribution Curve of the Fatty Acids of Plaques

The numbers in each fraction represent the per cent concentration of fatty acids as determined by gas-liquid chromatography.

be discussed first, because it is the largest fraction, and because the simplicity of its composition makes it particularly suitable for clarification of the manner of application of the various methods. The fraction consisted of a single peak by the countercurrent method, incompletely separated from the adjacent peaks. Paper chromatography of this peak revealed a single spot with the $\mathrm{Rf}$ of palmitic and oleic acids. As pointed out by others (39, 43), however, these methods, both of which succeed principally on the basis of differences in polarity of the substances being separated, are subject to the following limitation: If the chain length of a fatty acid is increased by two carbon atoms, the polarity is decreased; if the number of double bonds is increased by one, the polarity is increased. These opposite effects are usually about equal, so that the mobility ( $\mathrm{Rf}$ value) of a given fatty acid is about the same ${ }^{8}$ as that of the acid with two more carbons and one more double

8 This generalization seems not to hold for arachidonic acid, which is poorly separated from linoleic acid. According to the generalization, arachidonic and linolenic acids should run together. In practice, when known mixtures of fatty acids are chromatographed, arachidonic acid appears between linoleic and linolenic acids, more nearly superimposed on linoleic acid. bond. Gas-liquid chromatography, on the other hand, separates the fatty acids largely on the basis of molecular weight. In this respect it resembles distillation. The effect of double bonds is distinctly secondary. This method is capable of resolving the ambiguity remaining after application of the methods that achieve separation on the basis of polarity. The ambiguity may also be removed by hydrogenation of the fractions from the original counter-current distribution, followed by paper chromatography or a second run on the countercurrent apparatus.

It is not surprising, in view of the above considerations, that Fraction $\mathrm{D}$ could be separated by gas-liquid chromatography into two peaks having the retention volumes of known fatty acids of chain lengths 16 and 18, respectively. Furthermore, after hydrogenation of the material, two spots appeared on paper chromatograms, and these had the Rf of saturated fatty acids with 16 and 18 carbons. The $\mathrm{C}_{18}$ acid must have had a single double bond in its native, unhydrogenated state, since it moved with the $C_{16}$ saturated acid on paper and in the counter-current apparatus.

After alkali isomerization, the only absorption was a very small one at the wave length character- 
TABLE II

Fatty acids of atheromatous plaques*

\begin{tabular}{|c|c|c|c|c|c|c|c|c|c|c|c|c|c|c|}
\hline $\begin{array}{c}\text { Tube } \\
\text { number }\end{array}$ & $\begin{array}{c}\text { Frac- } \\
\text { tion }\end{array}$ & Weight & $\begin{array}{l}\text { Per } \\
\text { cent } \\
\text { of } \\
\text { total }\end{array}$ & $\begin{array}{l}\text { Iodine } \\
\text { value, } \\
\text { found }\end{array}$ & $\begin{array}{l}\text { Iodine } \\
\text { value, } \\
\text { calcu- } \\
\text { lated }\end{array}$ & $\begin{array}{l}\text { Tetra- } \\
\text { dec- } \\
\text { anoic } \\
\text { ("My- } \\
\text { ris- } \\
\text { tic") }\end{array}$ & $\begin{array}{l}\text { Hexa- } \\
\text { dec- } \\
\text { anoic } \\
\text { ("Pal- } \\
\text { mitic") }\end{array}$ & $\begin{array}{l}\text { Hexa- } \\
\text { dec- } \\
\text { enoic } \\
\text { ("Pal- } \\
\text { mito- } \\
\text { leic") }\end{array}$ & $\begin{array}{l}\text { Octa- } \\
\text { dec- } \\
\text { anoic } \\
\text { ("Ste- } \\
\text { aric") }\end{array}$ & $\begin{array}{c}\text { Octa- } \\
\text { dec- } \\
\text { enoic } \\
\text { ("Oleic") }\end{array}$ & $\begin{array}{l}\text { Octa- } \\
\text { decadi- } \\
\text { enoic } \\
\text { ("Lin- } \\
\text { oleic") }\end{array}$ & $\begin{array}{l}\text { Octa- } \\
\text { decatri- } \\
\text { enoic } \\
\text { ("Lin- } \\
\text { olenic") }\end{array}$ & $\begin{array}{c}\text { Eico- } \\
\text { sanoicł } \\
\text { ("Arach- } \\
\text { idic") } \\
\text { Eico- } \\
\text { senoic } \\
\text { Eico- } \\
\text { sadi- } \\
\text { enoic }\end{array}$ & $\begin{array}{l}\text { Eico- } \\
\text { satetra- } \\
\text { enoic } \\
\text { ("Arachi- } \\
\text { donic") }\end{array}$ \\
\hline \multirow{3}{*}{$\begin{array}{c}0-30 \\
31-75 \\
76-99 \\
100-143 \\
144-159 \\
160-200 \\
82-86 \\
123-127 \\
\text { Total mg. } \\
\text { Per cent } \\
\text { of total }\end{array}$} & \multirow{3}{*}{$\begin{array}{l}\mathrm{A} \S \\
\mathrm{B} \\
\mathrm{C} \\
\mathrm{D} \\
\mathrm{E} \\
\mathrm{F} \| \\
\mathrm{I} \\
\mathrm{II}\end{array}$} & $m g$. & \multirow{3}{*}{$\begin{array}{r}4.8 \\
18.2 \\
14.2 \\
38.1 \\
5.2 \\
5.8 \\
3.9 \\
9.7\end{array}$} & \multirow{3}{*}{$\begin{array}{r}46.4 \\
185.6 \\
161.0 \\
63.7 \\
24.2 \\
88.6\end{array}$} & \multirow{3}{*}{$\begin{array}{r}206.7 \\
182.9 \\
65.6\end{array}$} & $m g$. & $m g$. & $m g$ & $m g$. & $m g$. & $m g$. & $m g$. & $m g$. & $m g$. \\
\hline & & $\begin{array}{r}77.9 \\
293.1 \\
228.5 \\
614.5 \\
83.4 \\
94.7\end{array}$ & & & & $\begin{array}{c}21.6 \\
0 \\
0 \\
0\end{array}$ & $\begin{array}{c}0 \\
0 \\
179.4 \\
2.4\end{array}$ & $\begin{array}{c}59.7 \\
23.1 \\
0 \\
0\end{array}$ & $\begin{array}{c}0 \\
0 \\
0 . \\
70.9\end{array}$ & $\begin{array}{c}0 \\
0 \\
421.5 \\
\text { Trace }\end{array}$ & $\begin{array}{c}104.9 \\
189.9 \\
13.5 \\
0\end{array}$ & $\begin{array}{c}\text { Trace } \\
\mathbf{0} \\
\mathbf{0} \\
\mathbf{0}\end{array}$ & $\begin{array}{c}\mathbf{0} \\
\mathbf{0} \\
\mathbf{0} \\
\mathbf{1 0 . 1}\end{array}$ & $\begin{array}{c}106.9 \\
15.3 \\
0 \\
0\end{array}$ \\
\hline & & $\begin{array}{r}64.1 \\
156.2 \\
1,612.4 \\
100\end{array}$ & & & & $\begin{array}{c}0 \\
0 \\
21.6 \\
1.3\end{array}$ & $\begin{array}{r}0 \\
56.7 \\
238.5 \\
14.8\end{array}$ & $\begin{array}{c}6.9 \\
0 \\
89.7 \\
5.6\end{array}$ & $\begin{array}{c}0 \\
0 \\
70.9 \\
4.4\end{array}$ & $\begin{array}{c}0 \\
96.0 \\
517.5 \\
32.1\end{array}$ & $\begin{array}{r}57.2 \\
3.4 \\
369.0 \\
22.9\end{array}$ & $\begin{array}{c}\mathbf{0} \\
\mathbf{0} \\
\text { Trace } \\
\text { Trace }\end{array}$ & $\begin{array}{c}0 \\
0 . \\
10.1 \\
0.6\end{array}$ & $\begin{array}{c}0 \\
0 \\
122.2 \\
7.6\end{array}$ \\
\hline
\end{tabular}

* The amount of fatty acids was calculated from data obtained by counter-current distribution and gas-liquid chromatography.

$\dagger$ The iodine values were calculated from the percentages of fatty acids determined by gas-liquid chromatography.

$\ddagger$ The nature of these $C_{20}$ acids is not yet definitely established. Preliminary investigations indicate that they are $\mathrm{C}_{20}$ saturated and $\mathrm{C}_{20}$ with probably one and two double bonds.

\& Unidentified; probably mostly oxidized fatty acids with trace amounts of $\mathrm{C}_{14}, \mathrm{C}_{16}$, and $\mathrm{C}_{18}$ acids, and minimal triene absorption.

|| Unidentified; probably mostly polymerized fatty acids.

istic of a diene. It is reasonable to assume that this absorption was due to contamination from Fraction C.

Evidently Fraction D consisted mainly of a $\mathrm{C}_{16}$ saturated fatty acid (palmitic) and a $\mathrm{C}_{18}$ singly unsaturated fatty acid (presumably oleic), with a trace of diene (probably linoleic). Table II gives the composition of the fraction as determined by the combined techniques. The content of hexadecanoic $\left(\mathrm{C}_{18}\right.$, saturated $)$ and octadecenoic $\left(\mathrm{C}_{18}\right.$, one double bond) acids was calculated from the gasliquid chromatogram. The content of octadecadienoic acid $\left(\mathrm{C}_{18}\right.$, two double bonds, probably linoleic) was calculated from the alkali isomerization. The theoretical iodine value of the fraction, calculated from the above composition, was 65.6. The observed iodine value was 63.7. Thus, for this fraction, the methods employed were in satisfactory agreement.

Tubes 123 through 127, labeled Fraction II in Table II and comprising the peak tubes from Fraction $\mathrm{D}$, were analyzed separately. The composition of the material in the peak did not differ greatly from that in the limbs of the curve. In addition to $\mathrm{C}_{16}$ saturated and $\mathrm{C}_{18}$ one double bond, alkali isomerization revealed 2.2 per cent dienoic acid within this fraction. Fatty acids other than $\mathrm{C}_{18}$ and $\mathrm{C}_{18}$ could not be demonstrated by paper chromatography after hydrogenation or by gasliquid chromatography.

The fact that the percentage of dienoic acid was practically identical with that for Fraction D raises the possibility that a doubly unsaturated fatty acid of chain length greater than 18 carbons was present. One would not expect Fraction II to be so heavily contaminated with linoleic acid from Fraction C. If a longer chain dienoic acid was present, its concentration was too low to permit detection by paper chromatography after hydrogenation or by gas-liquid chromatography.

Fraction $C$ (tubes 76 through 99 less tubes 82 through 86). According to the generalization mentioned above, this fraction, one step greater in polarity than Fraction $\mathrm{D}$, might be expected to contain linoleic acid $\left(\mathrm{C}_{18}\right.$, two double bonds) and palmitoleic acid $\left(\mathrm{C}_{16}\right.$, one double bond $)$. Paper chromatograms showed a spot corresponding in $\mathrm{Rf}$ to these, and also a spot with the Rf of arachidonic acid. Evidently the resolution attainable by paper chromatography in this region exceeds that of the counter-current technique as used in this study. Gas-liquid chromatograms revealed $\mathrm{C}_{18}$, $\mathrm{C}_{18}$ and $\mathrm{C}_{20}$ acids, the main component being $\mathrm{C}_{18}$. It is presumed that the $\mathrm{C}_{20}$ acid was arachidonic, poorly resolved in the counter-current apparatus from palmitoleic and linoleic acids. 
Alkali isomerization confirmed these deductions. Eighty-one and one-tenth per cent of the fraction appeared to be a dienoic acid. By gas-liquid chromatography, 83.1 per cent was a $\mathrm{C}_{18}$ acid, presumably a diene in view of its mobility in the counter-current apparatus. Alkali isomerization indicated that 4.2 per cent of the fraction was a tetraenoic acid, and 0.95 per cent, pentaenoic. By gas-liquid chromatography, 6.7 per cent was $C_{20}$ acids. Table $\mathrm{V}$ shows these comparisons for this fraction, as well as for all of the other fractions on which such comparative studies were carried out.

Similar measurements were done on tubes 82 through 86, taken from the peak of Fraction C and labeled Fraction I. Being further removed in the distribution from Fraction $B$, these peak tubes contained immeasurably small amounts of tetraenoic and pentaenoic acids (by alkali isomerization). Otherwise the composition was similar to that of Fraction C.

The quantitative data for Fractions $\mathrm{C}$ and I, taken from the gas-liquid chromatograms, are included in Table II.

Fraction $B$ (tubes 31 through 75). According to the generalization about polarity, this fraction should contain arachidonic acid $\left(\mathrm{C}_{20}\right.$, four double bonds), as well as linolenic $\left(\mathrm{C}_{18}\right.$, three double bonds), if any is present, and myristic $\left(\mathrm{C}_{14}\right.$, saturated). In view of the lack of resolution from Fraction $\mathrm{C}$, one would also expect to find the other components of that fraction. As set forth in Tables II and VI, the actual findings were in accord with these predictions. In addition, significant quantities of more highly unsaturated acids were present (by isomerization). Spectrograms obtained after alkali isomerization revealed absorption peaks at $232,315,345$ and $374 \mathrm{~m} \mu$, indicating the presence of diene, tetraene, pentaene and hexaene acids. Table VII shows their quantities. There was no appreciable peak at $268 \mathrm{~m} \mu$ (triene peak). After hydrogenation of the fraction, a small peak with the retention volume of a $\mathrm{C}_{22}$ acid appeared in the gas-liquid chromatogram. No such peak could be seen before hydrogenation, presumably because the $\mathrm{C}_{22}$ fraction consisted of several different' highly unsaturated acids, each present in very small quantity and having slightly different retention volumes.

The presence of small amounts of $\mathrm{C}_{16}$ diene, in this fraction, cannot be excluded on the basis of our studies. Since the efficiency of our gas-liquid chromatography columns was rather low, and since counter-current distribution failed to separate the complex mixture of fatty acids present in this peak, the only method left was paper chromatography. Palmitolinoleic acid has an Rf value very close to that of linolenic acid. On paper chromatograms no iodine stainable spots could be detected that would suggest the presence of $\mathrm{C}_{16}$ diene. This would not, however, rule out the presence of such an acid, because paper chromatography, as used in this study, failed to detect fatty acids which constituted less than two per cent of a given mixture.

Fraction $A$ (tubes 0 through 30 ). This portion of the counter-current distribution consisted mostly of an unidentified, amorphous material, which showed some degree of general absorption in the region of 270 to $275 \mathrm{~m} \mu$, before alkali isomerization, suggesting the presence of oxidized fatty acids (46). Because of lack of sufficient material, no other studies were carried out.

Fraction $E$ (tubes 144 through 159). By gasliquid chromatography, this fraction was largely $\mathrm{C}_{18}$ acids, with small amounts of $\mathrm{C}_{16}$ and $\mathrm{C}_{20}$. In view of the low iodine value and the lack of an oleic acid spot on paper chromatograms, the principal component of this fraction was evidently stearic acid. Alkali isomerization showed the presence of 1.5 to 2 per cent of dienoic acid, probably due to a $\mathrm{C}_{20}$ acid with two double bonds.

Fraction $F$ (tubes 160 through 200). This fraction was made up of an oily material with trace amounts of $\mathrm{C}_{16}, \mathrm{C}_{18}$ and $\mathrm{C}_{20}$ acids. It showed several absorption bands in the ultraviolet after alkali isomerization. These bands may have been due to polymerized fatty acids. It has been demonstrated that in reversed phase paper chromatography the polymerized substances stay at the starting point of the chromatograms (47). In countercurrent distribution, the polymerized substances would be expected to favor the less polar moving phase.

In the routine analyses no $C_{12}$ acids were demonstrated. After preliminary vacuum distillation, however, trace amounts of $\mathrm{C}_{12}$ acids appeared in gas-liquid chromatograms from columns overloaded with the " $\mathrm{C}_{\mathbf{1 6}}$ " fraction.

Infrared analyses for trans acids were carried out on various samples by Dr. J. R. Chipault, of 
TABLE III

Fatty acids of normal plasma*

\begin{tabular}{|c|c|c|c|c|c|c|c|c|c|c|c|c|c|c|}
\hline $\begin{array}{c}\text { Tube } \\
\text { number }\end{array}$ & $\begin{array}{c}\text { Frac- } \\
\text { tion }\end{array}$ & Weight & $\begin{array}{l}\text { Per } \\
\text { cent } \\
\text { of } \\
\text { total }\end{array}$ & $\begin{array}{l}\text { Iodine } \\
\text { value, } \\
\text { found }\end{array}$ & $\begin{array}{l}\text { Iodine } \\
\text { value, } \\
\text { calcu- } \\
\text { lated† }\end{array}$ & $\begin{array}{c}\text { Tetra- } \\
\text { dec- } \\
\text { anoic } \\
\text { ("My- } \\
\text { ris- } \\
\text { tic") }\end{array}$ & $\begin{array}{c}\text { Hexa- } \\
\text { dec- } \\
\text { anoic } \\
\text { ("Pal- } \\
\text { mitic") }\end{array}$ & $\begin{array}{c}\text { Hexa- } \\
\text { dec- } \\
\text { enoic } \\
\text { ("Pal- } \\
\text { mito- } \\
\text { leic") }\end{array}$ & $\begin{array}{l}\text { Octa- } \\
\text { dec- } \\
\text { anoic } \\
\text { ("Stte- } \\
\text { aric") }\end{array}$ & $\begin{array}{c}\text { Octa- } \\
\text { dec- } \\
\text { enoic } \\
\text { ("Oleic") }\end{array}$ & $\begin{array}{l}\text { Octa- } \\
\text { dec- } \\
\text { adi- } \\
\text { enoic } \\
\text { ("Lin- } \\
\text { oleic") }\end{array}$ & $\begin{array}{l}\text { Octa- } \\
\text { decatri- } \\
\text { enoic } \\
\text { ("Lin- } \\
\text { olenic") }\end{array}$ & $\begin{array}{c}\text { Eico- } \\
\text { sanoicł } \\
\text { ("Arach- } \\
\text { idic") } \\
\text { Eico- } \\
\text { senoic } \\
\text { Eico- } \\
\text { sadi- } \\
\text { enoic }\end{array}$ & $\begin{array}{c}\text { Eico- } \\
\text { satetra- } \\
\text { enoic } \\
\text { ("Ara- } \\
\text { chi- } \\
\text { donic") }\end{array}$ \\
\hline \multirow[t]{2}{*}{$\begin{array}{c}0-113 \\
114-131 \\
132-159 \\
140-143 \\
160-200 \\
\text { Total mg. } \\
\text { Per cent } \\
\text { of total }\end{array}$} & \multirow[t]{2}{*}{$\begin{array}{l}\text { A } \\
\text { B } \\
\text { C } \\
\text { I } \\
\text { D\& }\end{array}$} & $\begin{array}{r}\text { mg. } \\
551.7 \\
191.9 \\
511.6 \\
122.8 \\
91.0 \\
1,469.0\end{array}$ & \multirow[t]{2}{*}{$\begin{array}{r}37.5 \\
13.1 \\
34.8 \\
8.3 \\
6.2\end{array}$} & \multirow[t]{2}{*}{$\begin{array}{r}168.4 \\
52.8 \\
62.3 \\
74.9\end{array}$} & \multirow[t]{2}{*}{$\begin{array}{r}179.8 \\
55.9 \\
62.2\end{array}$} & $\begin{array}{c}m g . \\
33.5 \\
0 \\
0 \\
0 \\
0 \\
33.5\end{array}$ & \begin{tabular}{r}
\multicolumn{1}{c}{$m g}$. \\
0 \\
79.1 \\
157.1 \\
47.2 \\
3.4 \\
286.8
\end{tabular} & $\begin{array}{c}m g . \\
101.7 \\
0 \\
0 \\
0 \\
0 \\
101.7\end{array}$ & $\begin{array}{c}m g . \\
0 \\
0 \\
0 \\
0 \\
83.2 \\
83.2\end{array}$ & $\begin{array}{c}m g . \\
0 \\
106.3 \\
354.5 \\
74.8 \\
0 \\
535.6\end{array}$ & $\begin{array}{c}m g . \\
326.8 \\
6.5 \\
0 \\
0 \\
0 \\
333.3\end{array}$ & $\begin{array}{c}\text { mg. } \\
\text { Trace } \\
\mathbf{0} \\
\mathbf{0} \\
\mathbf{0} \\
\mathbf{0} \\
\text { Trace }\end{array}$ & $\begin{array}{l}m g . \\
0 \\
0 \\
0 \\
0 \\
4.4 \\
4.4\end{array}$ & $\begin{array}{c}m g . \\
89.7 \\
0 \\
0 \\
0 \\
0 \\
89.7\end{array}$ \\
\hline & & 100 & & & & 2.3 & 19.5 & 6.9 & 5.6 & 36.5 & 22.7 & Trace & 0.3 & 6.1 \\
\hline
\end{tabular}

* The amount of fatty acids was calculated from data obtained by counter-current distribution and gas-liquid chromatography.

t See Table I.

$\ddagger$ The nature of these $C_{20}$ acids is not yet definitely established. Preliminary investigations indicate that they are $\mathrm{C}_{20}$ saturated and $\mathrm{C}_{20}$ with probably one and two double bonds.

$\$$ The high iodine value in this fraction is most likely due to the oily, unidentified material (probably polymerized fatty acids). Since we do not know the per cent of this substance in the fraction, the actual amount of acids, calculated from gas-liquid chromatography data, may be somewhat lower than indicated in the table. However, this should not introduce a significant error in the final calculations, because Fraction D constitutes a small percentage of the total fatty acids. The oleic acid contamination should have been less than 3 per cent since on paper chromatography no oleic acid was detected. Alkali isomerization revealed 1.6 to 2 per cent diene absorption. $C_{16}, C_{18}$ and $C_{20}$ acids were found by gas-liquid chromatography.

the Hormel Institute. The trans content, expressed in terms of methyl elaidate, was 6.5 per cent for the fatty acids of plaques and 2.7 per cent for the fatty acids of normal plasma. The significance of these findings is not clear at this time.
Fatty acids from total lipids of normal plasma, from cholesterol esters of atheromatous plaques, and from cholesterol esters of normal plasma

Analyses on these three materials were carried out in a manner similar to that described above in detail for the fatty acids from total lipids of

TABLE IV

Fatty acids of cholesterol esters of plaques*

\begin{tabular}{|c|c|c|c|c|c|c|c|c|c|c|c|c|c|c|}
\hline $\begin{array}{c}\text { Tube } \\
\text { number }\end{array}$ & $\begin{array}{c}\text { Frac- } \\
\text { tion }\end{array}$ & Weight & $\begin{array}{l}\text { Per } \\
\text { cent } \\
\text { of } \\
\text { total }\end{array}$ & $\begin{array}{l}\text { Iodine } \\
\text { value, } \\
\text { found }\end{array}$ & $\begin{array}{l}\text { Iodine } \\
\text { value, } \\
\text { calcu- } \\
\text { lated }\end{array}$ & $\begin{array}{c}\text { Tetra- } \\
\text { dec- } \\
\text { anoic } \\
\text { ("My- } \\
\text { ris } \\
\text { tic") }\end{array}$ & $\begin{array}{c}\text { Hexa- } \\
\text { dec- } \\
\text { anoic } \\
\text { ("Pal- } \\
\text { mitic") }\end{array}$ & $\begin{array}{l}\text { Hexa- } \\
\text { dec- } \\
\text { enoic } \\
\text { ("Pal- } \\
\text { mito- } \\
\text { leic") }\end{array}$ & $\begin{array}{l}\text { Octa- } \\
\text { dec- } \\
\text { anoic } \\
\text { ("Ste-- } \\
\text { aric") }\end{array}$ & $\begin{array}{c}\text { Octa- } \\
\text { dec- } \\
\text { enoic } \\
\text { ("Oleic") }\end{array}$ & $\begin{array}{l}\text { Octa- } \\
\text { dec- } \\
\text { adi- } \\
\text { enoic } \\
\text { ("Lin- } \\
\text { oleic") }\end{array}$ & $\begin{array}{l}\text { Octa- } \\
\text { decatri- } \\
\text { enoic } \\
\text { ("Lin- } \\
\text { olenic") }\end{array}$ & $\begin{array}{c}\text { Eico- } \\
\text { sanoict } \\
\text { ("Arach- } \\
\text { idic") } \\
\text { Eico- } \\
\text { senoic } \\
\text { Eico } \\
\text { sadi- } \\
\text { enoic }\end{array}$ & $\begin{array}{c}\text { Eico- } \\
\text { satetra- } \\
\text { enoic } \\
\text { ("Arachi- } \\
\text { donic") }\end{array}$ \\
\hline \multirow{4}{*}{$\begin{array}{r}0-70 \\
181-200 \\
71-105 \\
106-160 \\
161-180 \\
85-87 \\
127-129 \\
\text { Total mg. } \\
\text { Per cent } \\
\text { of total }\end{array}$} & \multirow{4}{*}{$\begin{array}{l}\text { A } \\
\text { B } \\
\text { C } \\
\text { D\& } \\
\text { I } \\
\text { II }\end{array}$} & $\begin{array}{l}m g . \\
533.1\end{array}$ & \multirow{4}{*}{\begin{tabular}{r|}
18.3 \\
32.7 \\
40.8 \\
1.0 \\
3.6 \\
3.5
\end{tabular}} & \multirow{4}{*}{$\begin{array}{r}202.6 \\
154.0 \\
72.0 \\
91.8\end{array}$} & \multirow{4}{*}{$\begin{array}{l}226.0 \\
180.0 \\
73.5\end{array}$} & $\begin{array}{l}m g . \\
17.6\end{array}$ & $\begin{array}{c}m g . \\
0\end{array}$ & $\begin{array}{l}m g . \\
86.9\end{array}$ & $\begin{array}{c}m g . \\
0\end{array}$ & $\begin{array}{c}m g . \\
0\end{array}$ & $\begin{array}{l}m g . \\
204.7\end{array}$ & $\begin{array}{c}m g . \\
\text { Trace }\end{array}$ & $\begin{array}{c}m g . \\
?\end{array}$ & $\begin{array}{c}m g . \\
224.5\end{array}$ \\
\hline & & $\begin{array}{r}950.2 \\
1,186.4 \\
29.7\end{array}$ & & & & $\begin{array}{l}\mathbf{0} \\
\mathbf{0}\end{array}$ & $\begin{array}{c}0 \\
237.3\end{array}$ & $\begin{array}{c}103.9 \\
0\end{array}$ & $\begin{array}{c}\mathbf{0} \\
\mathbf{0} \\
\text { Present }\end{array}$ & $\begin{array}{l}0 \\
925.2\end{array}$ & $\begin{array}{r}791.5 \\
23.6\end{array}$ & $\begin{array}{l}\mathbf{0} \\
\mathbf{0}\end{array}$ & $\begin{array}{c}\mathbf{0} \\
\mathbf{0} \\
\text { Present }\end{array}$ & $\begin{array}{c}54.7 \\
0\end{array}$ \\
\hline & & $\begin{array}{r}103.4 \\
103.8 \\
2,906.6\end{array}$ & & & & $\begin{array}{c}1.0 \\
0 \\
18.6\end{array}$ & $\begin{array}{c}0 \\
26.3 \\
263.6\end{array}$ & $\begin{array}{c}5.8 \\
0 \\
196.6\end{array}$ & $\begin{array}{c}0 \\
0 \\
\text { Present }\end{array}$ & $\begin{array}{c}0 \\
77.5 \\
1,002.7\end{array}$ & $\begin{array}{c}92.9 \\
0 \\
1,112.7\end{array}$ & $\begin{array}{c}\mathbf{0} \\
\mathbf{0} \\
\text { Trace }\end{array}$ & $\begin{array}{c}0 \\
0 \\
\text { Present }\end{array}$ & $\begin{array}{c}3.6 \\
0 \\
282.8\end{array}$ \\
\hline & & 100 & & & & 0.6 & 9.1 & 6.8 & & 34.5 & 38.3 & & & 9.7 \\
\hline
\end{tabular}

* The amount of fatty acids was calculated from data obtained by counter-current distribution and gas-liquid chromatography.

$\dagger$ See Table I.

$\ddagger$ The nature of these $C_{20}$ acids is not yet definitely established. Preliminary investigations indicate that they are $\mathrm{C}_{20}$ saturated and $\mathrm{C}_{20}$ with probably one and two double bonds.

$\S$ Mixture of octadecanoic, eicosanoic, eicosenoic and eicosadienoic. We have no quantitative data for oily material (probably polymerized fatty acids). 
TABLE V

Fatty acids of cholesterol esters of normal plasma*

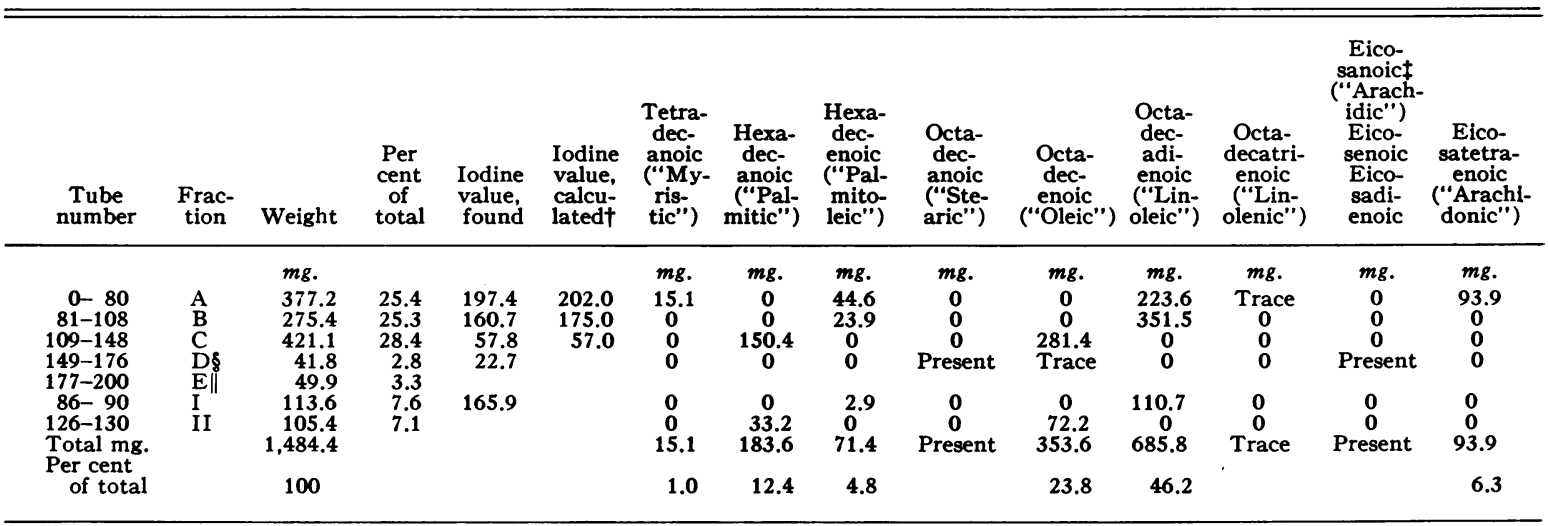

* The amount of fatty acids was calculated from data obtained by counter-current distribution and gas-liquid chromatography.

t See Table I.

$\ddagger$ The nature of these $C_{20}$ acids is not yet definitely established. Preliminary investigations indicate that they probably are $C_{20}$ saturated and $C_{20}$ with one and two double bonds.

$\$$ Forty-one and eight-tenths mg. equals 2.8 per cent mixture of octadecanoic, eicosanoic, eicosenoic and eicosadienoic. We have no quantitative data for these acids. Paper chromatography revealed trace amounts of oleic acid, in addition to stearic and $\mathrm{C}_{20}$ acids.

|| Forty-nine and nine-tenths mg. equals 3.3 per cent unidentified, probably polymerized substance.

atheromatous plaques. The results are presented in Figures 3, 4 and 5 and Tables III through VII.

\section{DISCUSSION}

\section{Methodology}

At the present stage of their development, we feel that the various methods of lipid analysis should be used in combination, with cross checks at every possible opportunity. No single method currently available is capable of providing a complete analysis of the complex mixtures of fatty acids from biological sources. With the methods based on separation, the possibility that parts of the mixture remain unresolved is always present, unless the separated components are subjected to further identification. The isomerization method is not valid, even in theory, unless the identity and extinction coefficient of the various polyenes present are known, a criterion that is seldom fulfilled. In practice, the results by this method are even more dubious, because of the compounding of errors by the multiple subtractions of large quantities from each other. One's confidence is increased somewhat if one always runs complete

TABLE VI

Summary of fatty acid composition of the various lipids studied

\begin{tabular}{|c|c|c|c|c|c|c|c|c|c|}
\hline Source of fatty acids & $\begin{array}{l}\text { Tetra- } \\
\text { decanoic } \\
\text { ("Myris- } \\
\text { tic") }\end{array}$ & $\begin{array}{l}\text { Hexa- } \\
\text { decanoic } \\
\text { ("Pal- } \\
\text { mitic") }\end{array}$ & $\begin{array}{l}\text { Hexa- } \\
\text { decenoic } \\
\text { ("Palmi- } \\
\text { toleic") }\end{array}$ & $\begin{array}{c}\text { Octa- } \\
\text { decanoic } \\
\text { ("Stearic") }\end{array}$ & $\begin{array}{c}\text { Octa- } \\
\text { decenoic } \\
\text { ("Oleic") }\end{array}$ & $\begin{array}{l}\text { Octadec- } \\
\text { adienoic } \\
\text { ("Lin- } \\
\text { oleic") }\end{array}$ & $\begin{array}{c}\text { Octadec- } \\
\text { atrienoic } \\
\text { ("Linolenic") }\end{array}$ & $\begin{array}{c}\text { Eico- } \\
\text { satetra- } \\
\text { enoic } \\
\text { ("Arachi- } \\
\text { donic") }\end{array}$ & $\begin{array}{l}\text { Eico- } \\
\text { sanoic- } \\
\text { Eico- } \\
\text { senoic- } \\
\text { Eicosadi- } \\
\text { enoic } \\
\text { ("Ara-" } \\
\text { chidic") }\end{array}$ \\
\hline \multirow{6}{*}{$\begin{array}{l}\text { Normal plasma } \\
\text { Plaques } \\
\text { Cholesterol esters } \\
\text { (normal plasma) } \\
\text { Cholesterol esters } \\
\text { (plaques) }\end{array}$} & $\%$ & $\%$ & $\%$ & $\%$ & $\%$ & $\%$ & $\%$ & $\%$ & $\%$ \\
\hline & 2.3 & 19.5 & 6.9 & 5.6 & 36.5 & 22.7 & Trace & 6.1 & 0.3 \\
\hline & 1.3 & 14.8 & 5.6 & 4.4 & 32.1 & 22.9 & Trace & 7.6 & 0.6 \\
\hline & 1.0 & 12.4 & 4.8 & $\mathrm{X}_{1}{ }^{*}$ & 23.8 & 46.2 & Trace & 6.3 & $\mathrm{X}_{2}{ }^{*}$ \\
\hline & & & & & & & & & \\
\hline & 0.6 & 9.1 & 6.8 & $\mathrm{X}_{3} \dagger$ & 34.5 & 38.3 & Trace & 9.7 & $x_{4} \dagger$ \\
\hline
\end{tabular}

* $\mathrm{X}_{1}$ plus $\mathrm{X}_{2}$ equals 2.8 per cent.

$\dagger X_{3}$ plus $X_{4}$ equals 1.0 per cent. 
TABLE VII

Comparison of the data obtained by gas-liquid chromatography (GLC) and alkali isomerization

\begin{tabular}{|c|c|c|c|c|c|c|c|c|}
\hline \multirow[b]{2}{*}{ Source } & \multirow[b]{2}{*}{ Fraction } & \multicolumn{2}{|c|}{ Linoleic acid } & \multirow[b]{2}{*}{ Triene } & \multicolumn{2}{|c|}{ Arachidonic acid } & \multirow[b]{2}{*}{ Pentaene } & \multirow[b]{2}{*}{ Hexaene } \\
\hline & & G.L.C. & $\begin{array}{l}\text { Isomeri- } \\
\text { zation } \\
\text { "diene"* }\end{array}$ & & G.L.C. & $\begin{array}{c}\text { Isomeri- } \\
\text { zation } \\
\text { "tetraene"† }\end{array}$ & & \\
\hline & & $\%$ & $\%$ & $\%$ & $\%$ & $\%$ & $\%$ & $\%$ \\
\hline Fatty acids of & A & & 2.3 & 1.8 & & 1.1 & 1.5 & 1.9 \\
\hline atheromatous & $\mathrm{B}$ & 35.8 & 34.1 & 2.0 & 36.4 & 27.6 & 2.7 & 4.8 \\
\hline plaques & $\mathrm{C}$ & 83.1 & 81.1 & 0 & 6.7 & 4.2 & 0.9 & 0 \\
\hline & D & & 2.2 & $\mathbf{0}$ & 0 & 0 & $\mathbf{0}$ & $\mathbf{0}$ \\
\hline & I & 89.1 & 84.9 & 0 & 0 & $\mathbf{0}$ & 0 & 0 \\
\hline & II & & 2.2 & 0 & 0 & 0 & 0 & 0 \\
\hline$\%$ of total & & 22.9 & 22.2 & 0.5 & 7.6 & 5.6 & 0.6 & 0.9 \\
\hline Fatty acids of & A & 59.2 & 53.6 & 3.3 & 16.3 & 16.3 & 2.3 & 3.8 \\
\hline normal plasma & B & & 3.4 & 0 & 0 & 0 & 0 & 0 \\
\hline$\%$ of total & & 22.7 & 20.2 & 1.2 & 6.1 & 6.1 & 0.9 & 1.4 \\
\hline Fatty acids of & A & 38.4 & 36.4 & 2.8 & 42.1 & 34.7 & 3.4 & 3.7 \\
\hline cholesterol & B & 83.2 & 82.7 & 2.8 & 5.7 & 3.1 & 0.6 & 1.4 \\
\hline esters of & C & 0 & 1.9 & 0.5 & 0 & 0 & 0.2 & 0 \\
\hline plaques & I & 89.9 & 86.8 & 0 & 0 & 1.7 & 0 & 0 \\
\hline$\%$ of total & & 38.3 & 37.6 & 1.6 & 9.7 & 7.4 & 0.9 & 1.0 \\
\hline Fatty acids of & A & 59.3 & 52.8 & 1.9 & 24.9 & 24.5 & 2.8 & 4.6 \\
\hline cholesterol & B & 93.6 & 83.5 & 1.0 & 0 & 0 & 0 & 0 \\
\hline $\begin{array}{l}\text { esters of normal } \\
\text { plasma }\end{array}$ & I & 97.4 & 86.3 & 0 & 0 & 0 & 0 & 0 \\
\hline$\%$ of total & & 46.2 & 41.1 & 0.7 & 6.3 & 6.2 & 0.7 & 1.2 \\
\hline
\end{tabular}

* "Diene" calculated as linoleic acid.

$\dagger$ "Tetraene" calculated as arachidonic acid.

spectra, as was done in this work, rather than merely measuring the absorption at the specified wave lengths. In the present study, the results obtained by isomerization fitted quite well with those from the other methods. This agreement is probably due, at least in part, to the fact that the polyenes other than dienoic and tetraenoic acids were present in quite small concentration.
Thus, the errors introduced into the estimation of the less highly unsaturated compounds due to errors in the measurement of the more unsaturated were minimal.

The rapid development of gas-liquid chromatography offers promise of eventually providing a single, rapid method for complete fatty acid analysis on small samples. As carried out in the cur-

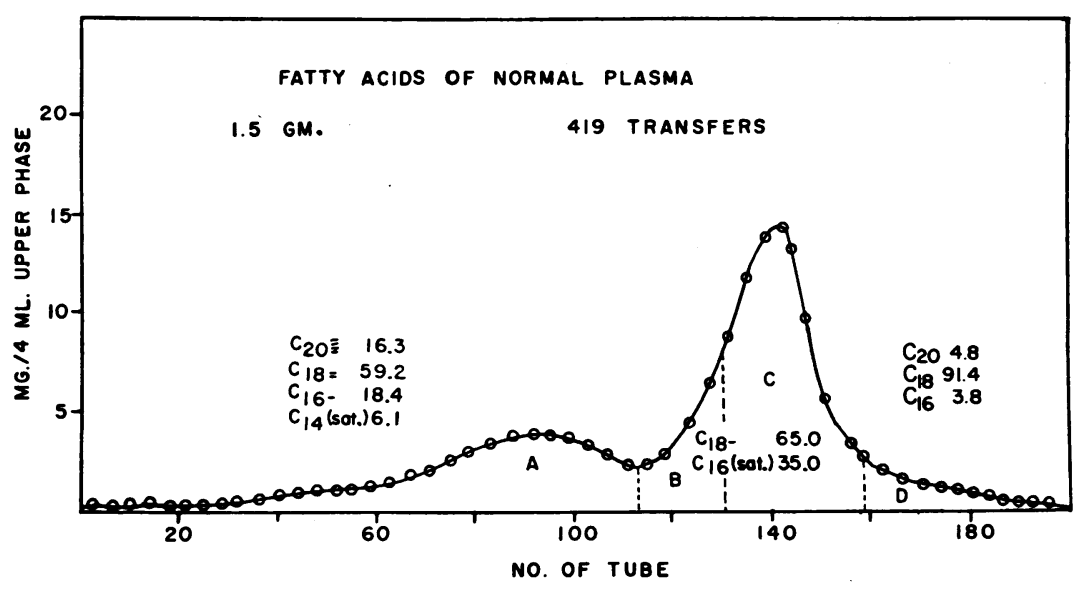

Fig. 3. Counter-Current Distribution Curve of the Fatty Acids of Normal Plasma

See explanation under Figure 2. 


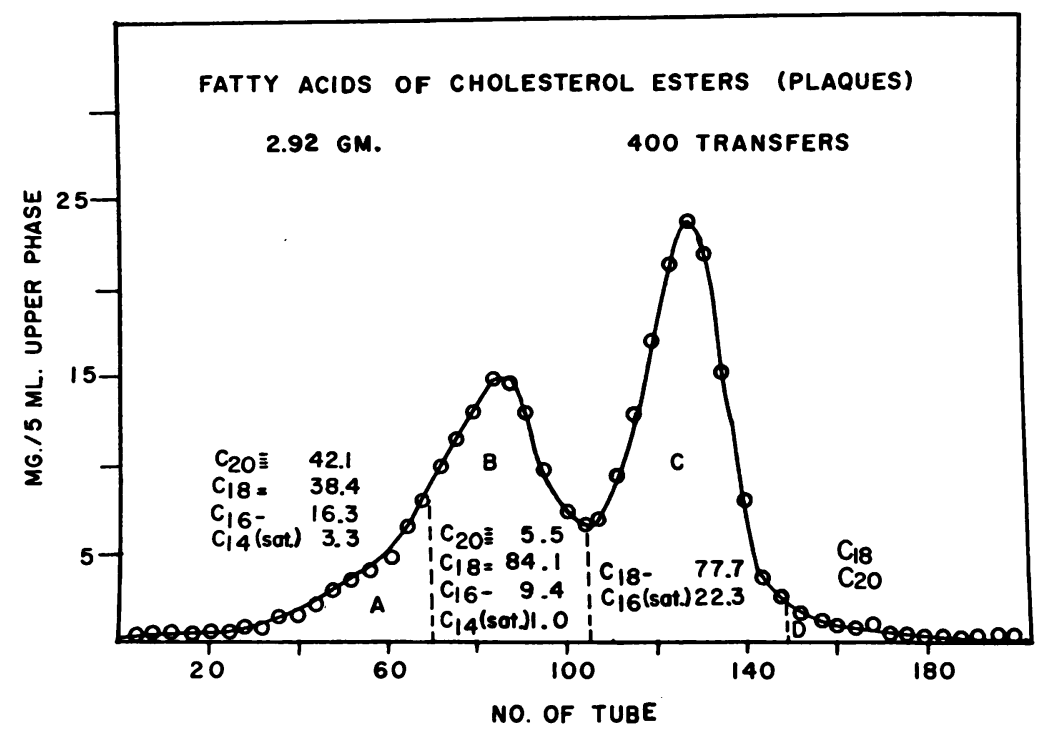

Fig. 4. Counter-Current Distribution Curve of the Fatty Acids of Cholesterol Esters of Plaques

See explanation under Figure 2.

rent study, the method suffered from the deficiency that accurate measurement of the amount of sample placed on the column was difficult, and the results had to be expressed as percentages of the total material recovered, rather than of that added. Furthermore, the resolving power of the column was insufficient to separate acids having the same chain length. It is our current practice to add an internal standard, to overcome the first of these deficiencies. Columns of much higher resolution have now been described, although preparation of such columns with regularity remains a difficult and highly empirical art.

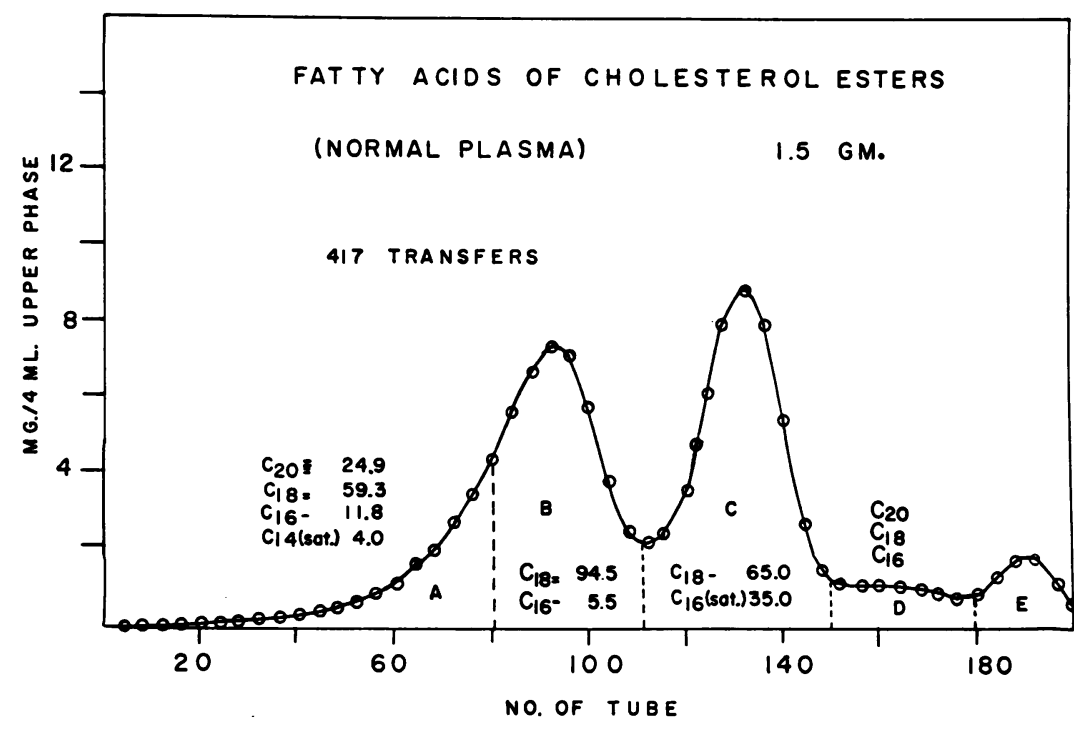

Fig. 5. Counter-Current Distribution Curve of the Fatty Acids of Cholesterol Esters of Normal Plasma

See explanation under Figure 2. 


\section{Source of material}

Some further comment is in order concerning the biological materials used. Because the methods required comparatively large quantities of fatty acids, the only practical approach was the pooling of samples from several individuals. The blood samples came from persons who were eating ordinary uncontrolled American diets. The effect of minor differences in these persons' dietary habits is unknown. The aortas were collected from persons of different ages, in whom the cause of death varied widely. We have no detailed information about their dietary habits, and we do not know the effect of such underlying diseases as diabetes mellitus, myocardial infarction, carcinoma, uremia, bacteremia and so forth. With improvement in the methodology, study of individual cases will be highly desirable.

\section{Comparisons with other work}

The finding of a high content of linoleic acid in cholesterol esters is in agreement with the work of Kelsey and Longenecker (20) for cow blood, and with that of Lipsky, Haavik, Hopper, and McDivitt (22) for human blood. James, Lovelock, Webb, and Trotter (23) were unable to demonstrate significant differences in the fatty acid composition of blood of persons with and without evidence of coronary artery disease. In view of our own findings, such a result would probably be anticipated.

The possibility that trace amounts of other fatty acids, as reported by James and associates (23), are present in the samples investigated cannot be excluded. It is quite possible that similar fatty acids are present in the plaques as well. Until the position of the double bonds in the unsaturated fatty acids isolated from blood and atheromatous plaques is known, a terminology which indicates only the number of double bonds and the carbon chain length is preferable to the more familiar names. In deference to custom, the familiar names were also included in this report.

\section{Significance of this study}

As noted in the introduction, we hoped to shed light on the mechanism of atheroma formation by this comparison of the fatty acid composition of plasma and of atheromatous plaques. Are the lipids deposited indiscriminately, regardless of their fatty acid composition, or are certain fatty acids particularly likely to be left behind as the lipoprotein molecules filter in and out of the arterial intima? Our analyses of the fatty acids of total lipids are compatible with the notion of indiscriminate deposition, but do not prove it because of the possibility that compensating differences exist in the various classes which make up the total lipids. In the case of the cholesterol esters, the ratio of linoleic acid to oleic acid was 1.9 in the plasma, but only 1.1 in the plaques. Because evaluation of the statistical significance of this difference is impossible, we prefer to defer further discussion of it, pending repetition of the analyses on individual patients. The following inference, however, does appear warranted: All of the various cholesterol esters of the plasma may be deposited in the arterial wall. None are specifically excluded. Although it is quite possible that population groups on different diets may have completely different patterns of fatty acids in the blood, it is difficult to conceive that those fatty acids would not be laid down if the proper conditions were present.

\section{CONCLUSIONS}

As summarized in Tables VI and VII, there appear to be neither qualitative nor gross quantitative differences between the total fatty acids of blood plasma and of atheromatous plaques. The linoleic acid of the cholesterol esters is relatively high in both blood and plaques. The ratio of linoleic to oleic acid is somewhat greater in the cholesterol esters of plasma than in those of plaques. No other significant differences are apparent.

\section{SUM MARY}

1. The fatty acids of the total lipids and the cholesterol esters of normal plasma and atheromatous plaques were investigated by counter-current distribution, determination of iodine value, alkali isomerization, gas-liquid chromatography, and paper chromatography before and after hydrogenation.

2. The fatty acids demonstrated were: saturated fatty acids $\mathrm{C}_{12}, \mathrm{C}_{14}, \mathrm{C}_{18}, \mathrm{C}_{18}$ and $\mathrm{C}_{20}$, and unsaturated fatty acids $\mathrm{C}_{16}$ with one and probably two double bonds, $\mathrm{C}_{18}$ with one, two and probably 
three double bonds, $\mathrm{C}_{20}$ with two and probably more double bonds, and $\mathrm{C}_{22}$ with unknown numbers of double bonds. Fatty acids of unknown chain length with five and six double bonds were also present.

3. The octadecadienoic acid content of cholesterol esters was found to be higher than that of total lipids, both in blood and plaques.

4. No qualitative and gross quantitative differences were found between the total fatty acids of normal plasma and atheromatous plaques. The linoleic acid content of cholesterol esters of normal plasma was found to be higher than that of atheromatous plaques. The reverse was found for oleic acid. The significance of this finding is unknown.

5. The data were interpreted as support for the concept that plaques are formed by filtration and indiscriminate deposition of blood lipids in the arterial wall.

\section{ACKNOWLEDGMENT}

We wish to express our appreciation to Dr. Hermann Schlenk of the Hormel Institute, Austin, Minn., for advice on the techniques of paper chromatography of fatty acids, for a generous gift of $a$-cyclodextrin, and for carrying out the distillation of the methyl esters of the fatty acids of atheromatous plaques.

\section{REFERENCES}

1. Aschoff-Marburg, L. Ein Beitrag zur Myelinfrage. Verh. dtsch. path. Ges. 1906, 10, 166.

2. Schoenheimer, R. Zur Chemie der gesunden und der atherosklerotischen Aorta. Hoppe-Seylers Z. physiol. Chem. 1926, 160, 61.

3. Schoenheimer, R. Zur Chemie der gesunden und der atherosklerotischen Aorta. Hoppe-Seylers Z. physiol. Chem. 1928, 177, 143.

4. Schoenheimer, R. 2. Mitteilung: Methodik zur quantitativen Trennung von ungesättigten und gesättigten Sterinen. Hoppe-Seylers Z. physiol. Chem. 1930, 192, 77.

5. Meeker, D. R., and Jobling, J. W. A chemical study of arteriosclerotic lesions in the human aorta. Arch. Path. (Chicago) 1934, 18, 252.

6. Zeek, P. M. A chemical analysis of atherosclerotic lesions in human aortas. Amer. J. Path. 1936, 12, 115.

7. Weinhouse, S., and Hirsch, E. F. Chemistry of atherosclerosis. I. Lipid and calcium content of the intima and of the media of the aorta with and without atherosclerosis. Arch. Path. (Chicago) 1940, 29, 31.

8. Page, I. H. Some aspects of the nature of the chemical changes occurring in atheromatosis. Ann. intern. Med. 1941, 14, 1741.

9. Barr, D. P., Russ, E. M., and Eder, H. A. Proteinlipid relationships in human plasma. II. In atherosclerosis and related conditions. Amer. J. Med. 1951, 11, 480.

10. Gertler, M. M., Garn, S. M., and Lerman, J. The interrelationships of serum cholesterol, cholesterol esters and phospholipids in health and in coronary artery disease. Circulation 1950, 2, 205.

11. Gutman, A. B. Present status of atherosclerosis as a derangement of lipid metabolism. Amer. J. Med. 1953, 14, 1.

12. Keys, A. Cholesterol, "giant molecules," and atherosclerosis. J. Amer. med. Ass. 1951, 147, 1514.

13. Gofman, J. W., Jones, H. B., Lindgren, F. T., Lyon, T. P., Elliott, H. A., and Strisower, B. Blood lipids and human atherosclerosis. Circulation 1950, 2, 161.

14. Gofman, J. W., Lindgren, F., Elliott, H., Mantz, W., Hewitt, J., Strisower, B., and Herring, V. The role of lipids and lipoproteins in atherosclerosis. Science 1950, 111, 166.

15. Gofman, J. W., Glazier, F., Tamplin, A., Strisower, B., and De Lalla, O. Lipoproteins, coronary heart disease, and atherosclerosis. Physiol. Rev. 1954, 34, 589.

16. McArthur, C. S. The acetone-soluble lipid of the atheromatous aorta. Biochem. J. 1942, 36, 559.

17. Wiese, H. G., and Hansen, A. E. Semimicromethod for unsaturated fatty acids of blood serum. J. biol. Chem. 1953, 202, 417.

18. Herb, S. F., and Riemenschneider, R. W. Spectrophotometric micromethod for determining polyunsaturated fatty acids. Analyt. Chem. 1953, 25, 953.

19. Evans, J. D., Waldron, J. M., Oleksyshyn, N. L., and Riemenschneider, R. W. Polyunsaturated fatty acids in normal human blood. J. biol. Chem. 1956, 218, 255.

20. Kelsey, F. E., and Longenecker, H. E. Distribution and characterization of beef plasma fatty acids. J. biol. Chem. 1941, 139, 727.

21. Michalec, C. The nature of cholesterol esters in human blood serum. Biochim. biophys. Acta 1956, 19, 187.

22. Lipsky, S. R., Haavik, A., Hopper, C. L., and McDivitt, R. W. The biosynthesis of the fatty acids of the plasma of man. I. The formation of certain chromatographically separated higher fatty acids of the major lipide complexes from acetate-1- $\mathrm{C}^{13}$. J. clin. Invest. 1957, 36, 233.

23. James, A. T., Lovelock, J. E., Webb, J., and Trotter, W. R. The fatty acids of the blood in coronaryartery disease. Lancet 1957, 272, 705.

24. Snapper, I. Chinese Lessons to Western Medicine. New York, Interscience Publishers, Inc., 1941, pp. 30-31.

25. Shapiro, W. E., Estes, E. H., Jr., and Hilderman, 
H. L. The effect of unsaturated fats on serum lipids in normal, active subjects. Clin. Res. Proc. 1957, 5, 107.

26. Sinclair, H. M. Deficiency of essential fatty acids and atherosclerosis, etcetera. Lancet 1956, 270, 381.

27. Gould, R. G. Lipid metabolism and atherosclerosis. Amer. J. Med. 1951, 11, 209.

28. Ahrens, E. H., Jr., Tsaltas, T. T., Hirsch, J., and Insull, W., Jr. Effects of dietary fats on the serum lipides of human subjects (abstract). J. clin. Invest. 1955, 34, 918.

29. Bronte-Stewart, B., Antonis, A., Eales, L., and Brock, J. F. Effects of feeding different fats on serumcholesterol level. Lancet 1956, 270, 521.

30. Beveridge, J. M. R., Connell, W. F., and Mayer, G. A. Dietary factors affecting the level of plasma cholesterol in humans: The role of fat. Canad. J. Biochem. 1956, 34, 441.

31. Keys, A., Anderson, J. T., and Grande, F. "Essential" fatty acids, degree of unsaturation, and effect of corn (maize) oil on the serum-cholesterol level in man. Lancet 1957, 272, 66.

32. Folch, J., Ascoli, I., Lees, M., Meath, J. A., and Le Baron, F. N. Preparation of lipide extracts from brain tissue. J. biol. Chem. 1951, 191, 833.

33. Craig, L. C., Gregory, J. D., and Hausmann, W. Versatile laboratory concentration device. Analyt. Chem. 1950, 22, 1462.

34. Borgström, B. Investigation on lipid separation methods. Separation of cholesterol esters, glycerides, and free fatty acids. Acta physiol. scand. 1952, 25, 111.

35. Lowry, O. H., Roberts, N. R., Leiner, K. Y., Wu, M., and Farr, A. L. The quantitative histochemistry of brain. I. Chemical methods. J. biol. Chem. 1954, 207, 1.

36. Sperry, W. M., and Webb, M. A revision of the
Schọenheimer-Sperry method for cholesterol determination. J. biol. Chem. 1950, 187, 97.

37. Abell, L. L., Levy, B. B., Brodie, B. B., and Kendall, F. E. A simplified method for the estimation of total cholesterol in serum and demonstration of its specificity. J. biol. Chem. 1952, 195, 357.

38. Craig, L. C., Hausmann, W., Ahrens, E. H., Jr., and Harfenist, E. J. Automatic countercurrent distribution equipment. Analyt. Chem. 1951, 23, 1236.

39. Ahrens, E. H., Jr., and Craig, L. C. Separation of the higher fatty acids. J. biol. Chem. 1952, 195, 299.

40. Wijs Method, Official Methods of Analysis of the Association of Official Agricultural Chemists. Washington, D. C., Association of Official Agricultural Chemists, 1955 , p. 465.

41. Kolthoff, I. M., and Bovey, F. A. Amperometric titration of Styrene with potassium bromate. Analyt. Chem. 1947, 19, 498.

42. Pack, F. C., Planck, R. W., and Dollear, F. G. Determination of the total unsaturation of Tung oil by catalytic hydrogenation. J. Amer. Oil Chem. Soc. 1952, 29, 227.

43. Mangold, H. K., Lamp, B. G., and Schlenk, H. Indicators for the paper chromatography of lipids. J. Amer. chem. Soc. 1955, 77, 6070.

44. Diazomethane, Organic Syntheses, Collective Volume IIa, A. H. Blatt, Ed. New York, John Wiley \& Sons, Inc., 1943, p. 165.

45. Cropper, F. R., and Heywood, A. Improvements in vapour-phase chromatography at relatively high temperatures. Nature (Lond.) 1954, 174, 1063.

46. Holman, R. T., Lundberg, W. O., Lauer, W. M., and Burr, G. O. Spectrophotometric studies of the oxidation of fats. I. Oleic acid, ethyl oleate, and elaidic acid. J. Amer. chem. Soc. 1945, 67, 1285.

47. Schlenk, H., Gellerman, J. L., Tillotson, J. A., and Mangold, H. K. Paper chromatography of lipides. J. Amer. Oil Chem. Soc. 1957, 54, 377. 